\title{
Psychological Contract Breach and Union Commitment Revisited: Evidence from Chinese Employees
}

\author{
Ji-Young Ahn ${ }^{1}$, Xia Lei ${ }^{1}$ and Joohee Han ${ }^{2, *}$ \\ 1 Ewha School of Business, Ewha Womans University, Seoul 03760, Korea; jy-ahn@ewha.ac.kr (J.-Y.A.); \\ leixiaewha@naver.com (X.L.) \\ 2 Department of Business Administration, Gachon University, Seongnam-si 13120, Gyeonggi-do, Korea \\ * Correspondence: jhhan0729@gachon.ac.kr
}

Citation: Ahn, J.-Y.; Lei, X.; Han, J. Psychological Contract Breach and Union Commitment Revisited: Evidence from Chinese Employees. Sustainability 2021, 13, 12034. https:/ / doi.org/10.3390/su132112034

Academic Editor: Hyo Sun Jung

Received: 8 October 2021

Accepted: 26 October 2021

Published: 31 October 2021

Publisher's Note: MDPI stays neutral with regard to jurisdictional claims in published maps and institutional affiliations.

Copyright: (C) 2021 by the authors. Licensee MDPI, Basel, Switzerland. This article is an open access article distributed under the terms and conditions of the Creative Commons Attribution (CC BY) license (https:// creativecommons.org/licenses/by/ $4.0 /)$.

\begin{abstract}
From the social exchange theory, this study examines the relationship between psychological contract breach, organizational cynicism, and union commitment, as well as the interaction effect of perceived union dual identity on the relationship between organizational cynicism and union commitment. We argue that contract breach has a positive impact on union commitment, and this relationship is mediated by organizational cynicism. Moreover, we suggest that the perceived union dual identity moderates the relationship between the two. To examine this, we sampled 371 employees of Chinese non-state-owned firms in 2019. The results show that, in the Chinese context, the psychological contract breach has a positive impact on organizational cynicism and union commitment. This relationship is weaker when the perceived union identity (state-oriented) is higher; it is stronger when the perceived union identity (labor-oriented) is higher.
\end{abstract}

Keywords: social exchange theory; psychological contract breach; union commitment; organization cynicism; perceived union identity

\section{Introduction}

A psychological contract is an expression of belief in the mutual obligation between an individual and an organization and consists of the latter's promises and the former's obligations [1]. Prior studies on psychological contract focused on the consequences of a psychological contract breach when an organization does not comply with its obligations [2]. They also showed that such violations have negative effects on employees' attitudes and behaviors toward the organization regarding job satisfaction, trust, and organizational commitment [3-7]. Specifically, the relationship between psychological contract breach and union commitment has gained popularity worldwide [8,9]. This is because employees tend to use the power of trade unions to protect their interests during a psychological contract breach $[10,11]$.

Despite its relevance, the relationship between psychological contract breach and union commitment has not received much attention in the Chinese context. This might be because, unlike the trade unions in Europe or the U.S., it is an extension of the state power institutions, which not only promotes the stable development of the organization, but also safeguards the rights and interests of employees, coordinates labor disputes, organizes cultural activities, and helps families with difficulties [12,13]. Specifically, Chinese unions have a 'dual identity' and are not completely independent of the state. Hence, they cannot represent employees' interests. With the rapid development of China's social economy, the status and role of the Chinese unions have also undergone major changes. The union as a representative of employees and negotiations with enterprises was re-emphasized; it plays an important role in social and economic development.

However, the relationship between psychological contract breach and union commitment is considered mixed, at best, in the literature. Evidence shows a positive relationship between psychological contract breach and union commitment. When employers fail to 
maintain a balance by not fulfilling their obligations, a psychological contract breach occurs [2], which can result in job dissatisfaction, turnover intention, negative behaviors [14], organizational cynicism [15,16], and union commitment [17]. However, an organization's failure to comply with or undermine the contract will reduce the employees' organizational commitment level and decrease their union commitment, simultaneously [18]. This empirical inconsistency in the findings of the relationship between psychological contract breach and union commitment may show that individuals or firms differ extensively in their ability to deal with the negative impact of a breach. The prevailing discipline notes another possibility of mixed results, which is an unexplored mechanism through which the psychological contract breach affects employee commitment to the union. That is, the important question is how such a relationship can occur and how the negative effects of psychological contract breach on union commitment can be mitigated. Hence, a study to examine the potential mediating and/or moderating factors in understanding this relationship between employees and the inherent factors in the workplace, which would lead to or influence union commitment, is needed. Thus, this study aims to revisit the relationship between psychological contract breach and multifaceted union commitment and provide a more comprehensive model of the relationship.

\subsection{Theory and Hypotheses}

\subsubsection{Psychological Contract Breach and Union Commitment}

As defined above, a psychological contract is a belief in the mutual obligation or reciprocity between employee and employer in exchange for employee commitment to organizational rewards [1]. When employees perceive a psychological contract breach, and the individual employees do not have enough power to make the organization change the poor working conditions, it can prompt the union to urge the organization to complete its unfinished responsibility by expressing their dissatisfaction [17]. An organization's failure to comply with or undermine the psychological contract between employees can be major cause of employee frustration; it can reduce the organizational commitment level and increase their union commitment [18]. Social exchange theory lends support to explain the phenomena in much detail, which suggests that relationships between individuals are defined through mutual social obligations [19]. According to social exchange theory, the action of one party relates to the reaction of the other party through reciprocity [20]. When employers in the organization fail to maintain a balance by not fulfilling its obligation, a breach of the psychological contract occurs [2], which can result in negative attitudes, such as job dissatisfaction, turnover intention, negative behaviors [14], organizational cynicism $[15,16]$ and union commitment [21]. Thus, based on the above analysis, this study proposes the following.

Hypothesis 1 (H1). The psychological contract breach between employees and organizations has a positive impact on union commitment.

\subsubsection{The Mediating Effect of Organization Cynicism}

Cynicism largely arises from a specific environmental condition, which is related to individual cognition. It reflects a negative emotion, such as frustration, disillusionment, and mistrust of the outside world [15]. Cynicism is an attitude consisting of an emotional element of negative feelings and disappointment as well as conviction of doubt [22,23]. Ferris et al. [23] consider organizational cynicism to be perceptions of self-centeredness, exploitation, misuse, partiality and nepotism at work. Various factors are attributed toward the development of organizational cynicism among employees. For example, it can be an outcome of employees' emotional responses [24], perceptions of psychological contract violation [25], wrong manifestation [26], lack of trust [27], biased employment decision-making process [28], organizational change [29,30], perceived injustice [31], negative feelings, such as disappointment from work and exhaustion [32], poor work environment [33], and overestimated executive compensation [22]. A psychological contract 
breach affects the employee's belief and ultimately causes changes in their attitude and behavior $[2,4]$, inducing organizational cynicism $[15,16,34]$. Frustration and disappointment result in aggressive behavior [35]. A reaction of this negative emotion can be an employee joining the union [36]. A study by Kuruvilla et al. [37] also established the impact of frustration-aggression on employee unionization in Japan. Many activities performed by the conflict between management and employee are termed as militant activities [38], which obviously are under the category of aggressive behavior. Dominant characteristic of organizational cynicism is employee frustration [15], which results in hostility [39]. Therefore, this study examines employee cynicism as a mediator between psychological contraction and union commitment.

Hypothesis 2 (H2). Organizational cynicism mediates the relationship between psychological contract breaches and union commitment.

\subsubsection{The Moderating Effect of Perceived Union Identity}

We further explore the possibility that individual differences may moderate the relationship between cynicism and union commitment as perceived union identity. Specifically, we examine the role of perceived union identity in examining the psychological contract and commitment to the union with special emphasis on how perceived union identity may mitigate the presumed adverse effects of organizational cynicism. Employee unionization is characterized by association and collective bargaining [40]; this association among employees can differ in different levels of union identity perception. The prior research believes that [30], under the communist system in China, the trade union plays a dual function, representing the overall interests of the state (state-oriented) and workers (labororiented). Trade unions in China have a dual identity regarding the nation and the worker community [31]. It is a tool for the state and workers' organizations. Moreover, within the framework of the national corporatist system, the nature of the dual identity of unions will exist for a long time.

Prior studies examine the relationship between the party union and the masses after the founding of New China from the perspective of the "conveyor belt". For example, Harper [41] believes that the union's role, being that of a conveyor belt, has a two-way transmission function: the top-down approach regarding the party's policy for the staff and workers, and the bottom-up approach that reflects the wishes and requirements of the staff. The Chinese union tends to take into accounts the core task of the party in each period as their main task [42], implement the party's policies for the staff and the masses, and unite the workers and the masses for the party [43]. Therefore, as the conveyor belt of the staff and the party, Chinese unions have played a dual role. The unions are regarded as an extension of the party and government functions within the enterprise, shouldering the responsibility of safeguarding the national interests and promoting stable development of the enterprise, being the bridge for the communication between the management and the employee, representing the employee's rights and interests. They were given the task of safeguarding employee rights, coordinating labor disputes, organizing cultural activities, and helping employees with difficulties [44,45].

The reform of China's market economic system has promoted direct and serious conflicts in this dual identity. It often changed the relationship between the state and workers for the sake of workers' interests [43]. When workers think that the trade union is a part of the state (state-oriented), that is, that it exists as a supporting and dependent institution of the state, it mainly implements national policies and does not pay attention to representing and safeguarding the interests of workers. Social exchange theory suggests that two specific aspects of organizational context may be influential in understanding the interaction effect of perceived union dual identity on the relationship between organizational cynicism and union commitment. First, the perceived identity between the members has a positive relationship with the ability of the members in the workplace to adjust to changing environmental demands through modification or termination of the agreement [46]. Second, 
the interdependence of the partner on the union commitment may be an important factor that influences the relationship between organizational cynicism and union commitment. In general, researchers have argued that dependency may serve to commit the partner to the union commitment, thereby increasing the longevity of the relationship [47]. Based on social exchange theory, workers no longer believe that trade unions are their protectors and are disappointed with their performance. When they generate organizational cynicism, they are more likely to be disappointed with the union and do not seek help from it. This leads to the following hypothesis.

Hypothesis 3 (H3). The positive relationship between organizational cynicism and union commitment is weaker when the perceived union identity (state-oriented) is higher.

On the other hand, when employees perceive labor-oriented union, the perception of organizational cynicism will create tension within employees, motivating them to resolve the tension. Likewise, we maintain that employees who perceive organization cynicism would have fewer psychological contract breaches and would be more likely to increase their commitment to union membership, due to a strong sense of reciprocity. Therefore, we posit that perceived labor-oriented union identity mitigates the negative aspect of organization cynicism, which in turn can lead to strengthening the effect of cynicism on union commitment. For instance, Wenxia [48] took Walmart's establishment of trade unions in China and found that their protection rights and functions of the unions were highly valued under the new situation of foreign-invested enterprises. Put differently, when the union is a more employee-oriented social organization, it is expected that such developments may increase the employees' confidence and trust in the trade union in enhancing employee welfare. Based on the above analysis, this study proposes the following hypothesis.

Hypothesis 4 (H4). The positive relationship between organizational cynicism and union commitment is stronger when perceived union identity (labor-oriented) is higher.

\section{Materials and Methods}

\subsection{Data Collection and Sample Description}

This study selected the sample of the employees of non-state-owned enterprises in Shandong Province, China, in 2019. To test the hypotheses, surveys were conducted on trade union members, non-union members, and management personnel of non-stateowned enterprises. A total of 600 surveys were distributed, and 400 were returned, with the response rate of $66.7 \%$. All subjects participated voluntarily. A total of 371 surveys were used for the analysis. Table 1 shows the demographic characteristics of the survey respondents in the sample, including gender, age, education, job position, and salary. .

\subsection{Measurement}

Psychological contract breach: We used Xianguo et al. [49] and Rousseau's [50] psychological contract scale to assess the psychological contract breach in the Chinese context, such as "The company takes care of the personal lives of its employees", "The company provides opportunities for my career development", and "I am treated fairly at the company compared to other companies", etc. Respondents indicated the degree with which they agree with this statement, using a 5-point scale ranging from 1 (not at all) to 5 (absolutely). There were nine items in total which were reverse coded since our variable of interest is the breach of psychological contract. The higher score denoted that the employee experienced a higher level of psychological contract breach. It is noted that Cronbach' alpha was 0.913. 
Table 1. Sample description.

\begin{tabular}{|c|c|c|c|}
\hline Classification & Item & Frequency & Percent \\
\hline \multirow{2}{*}{ gender } & male & 246 & 66.3 \\
\hline & female & 125 & 33.7 \\
\hline \multirow{7}{*}{ age } & below 20 & 0 & 0 \\
\hline & $20 \sim 25$ & 37 & 10 \\
\hline & $26 \sim 30$ & 98 & 26.4 \\
\hline & $31 \sim 35$ & 173 & 46.4 \\
\hline & $36 \sim 40$ & 54 & 14.6 \\
\hline & $40 \sim 50$ & 7 & 1.9 \\
\hline & above 50 & 2 & 0.5 \\
\hline \multirow{4}{*}{ education } & below junior college & 98 & 26.4 \\
\hline & junior college & 191 & 51.5 \\
\hline & bachelor's & 79 & 21.3 \\
\hline & master's and above & 3 & 0.8 \\
\hline \multirow{4}{*}{ job level } & worker & 234 & 63.1 \\
\hline & lower management & 83 & 22.4 \\
\hline & middle management & 48 & 12.9 \\
\hline & senior & 6 & 1.6 \\
\hline \multirow{4}{*}{ income/month } & RMB 2000 and below & 77 & 20.8 \\
\hline & RMB 2000 5000 & 209 & 56.3 \\
\hline & RMB 5000 8000 & 73 & 19.7 \\
\hline & RMB 8000 and above & 12 & 3.2 \\
\hline \multirow{2}{*}{ union member } & yes & 251 & 67.7 \\
\hline & no & 120 & 32.3 \\
\hline \multirow{4}{*}{ company size } & below 100 & 15 & 4 \\
\hline & $100 \sim 500$ & 152 & 41 \\
\hline & $500 \sim 1000$ & 129 & 34.8 \\
\hline & above 1000 & 75 & 20.2 \\
\hline \multirow{4}{*}{ company profit } & $6,000,000$ & 14 & 3.8 \\
\hline & $10,000,000$ & 162 & 43.7 \\
\hline & $14,000,000$ & 127 & 34.2 \\
\hline & $22,000,000$ & 68 & 18.3 \\
\hline \multirow{3}{*}{ company age } & $0-5$ years & 40 & 10.8 \\
\hline & $6-10$ years & 89 & 24 \\
\hline & 11 years and above & 242 & 65.2 \\
\hline sample number & & 371 & \\
\hline
\end{tabular}

Organizational cynicism: We used eight items based on Dean et al. [51], which includes "I feel depressed and disappointed when I think about the company", "I am disappointed in the say the company handle the business", and "I often laugh at the company's slogan and action" to capture the level of organizational cynicism which may be experienced by the employees in the enterprise. The Cronbach' alpha was noted at 0.910.

Perceived Union identity: This was measured by two variables: union identity (stateoriented) and union identity (labor-oriented). Prior studies in the Chinese context suggest that these two measures are theoretically and empirically independent based on the 'dual function' of Chinese Union [42,52]. Perceived union identity (state-oriented) is measured by a three item-scale based on Zhenglin [52], which states "I think the union is just a department of the company", "I think the union is a megaphone of the communist party", and "I think the union is a tool for managing employees". On the other hand, we used Jinn's [53] four-item scale to measure the second identity variable: perceived employeeoriented union identity. This variable captures the degree of union representation by Verma and Kochan [54], which states "I think the union is the representative of employees' right", "The union can coordinate the labor disputes", "The union organize cultural events to 
enrich employees' lives", and "The union will help poor employees". The Cronbach alphas were 0.858 and 0.770 , respectively.

Union Commitment: This was measured by a nine-item scale based on Loughlin et al. [55], which captures the three aspects of union loyalty, union willingness, and union responsibilities. It includes "I plan to be a member of the union in the future", "I feel very proud to be a member of the union", and "I am willing to put more time and efforts to do activities in Unions". The Cronbach's alpha was noted at 0.899 in the study.

The KMO value and Bartlett's sphere test presented the appropriateness of using factor analysis on the dataset to further investigate the data validity $[45,53]$. The range of $\mathrm{KMO}$ values of the above variables in the study was from 0.81 to 0.90 , which is in the range of 0.50 to 1 [51], indicating that the data are suitable for further factor analysis. Then, we conducted the exploratory factor analysis, and the results showed that the factor loading coefficients were greater than 0.5 , implying the validity of the main variables we operationalized [55].

Control Variables: We included several demographic variables to control for potential compounding effects on union commitment or union membership, such as gender, age, education, job position, and income [56]. We also controlled for firm characteristics that affect independent or dependent variables of the study, including company age, size, and firm performance [55].

\section{Results}

Table 2 presents the descriptive statistics of each variable and correlation matrix. It shows that the psychological contract breach was positively correlated with union commitment $(\mathrm{r}=0.219, p<0.01)$. The mean of union commitment is 2.22 out of 5 . It is noted that organization cynicism has a significantly positive correlation with union commitment and is also positively correlated with psychological contract breach.

Table 3 shows the results of hierarchical multiple regression analyses of union commitment. In all models, the highest variation inflation factor (VIF) of the variables was 1.880 , which is presented as being much lower than the cut-off point of 10 , indicating no multicollinearity issue in our sample [57]. Model 1 in Table 3 includes only the use of the control variables. As noted in model 2 of Table 3, psychological contract breach has a positive relationship with union commitment $(\beta=0.173, p<0.01)$, and model 2 has significantly more explanatory power than was noted in model 1 . We present that these findings support $\mathrm{H} 1$ that psychological contract breach between employees and organizations is positively associated with union commitment.

For H 2, we used model 2 and model 3 to test a mediating effect of organization cynicism between psychological contract breach and union commitment. We tested a mediation model, using Baron and Kenny's [58] model and the Sobel test to test the mediating effect of organization cynicism between psychological contract breach and union commitment. In model 3 of Table 3, when organization cynicism is included in the model, the regression coefficient of psychological contract breach is significantly decreased $(\beta=0.046, p<0.01)$, compared to $\beta=0.153(p<0.01)$ in model 2 . The results represent that organization cynicism partially mediates the relationship between the psychological contract breach and union commitment, which supports $\mathrm{H}$ 2. Such a mediation effect is also confirmed by the Sobel test [57]. The Sobel test statistic is 2.487, which is larger than 1.96 , indicating the existence of the mediation effect. 
Table 2. Description And Correlation Analysis Result.

\begin{tabular}{|c|c|c|c|c|c|c|c|c|c|c|c|c|c|c|}
\hline & Mean & S.D. & 1 & 2 & 3 & 4 & 5 & 6 & 7 & 8 & 9 & 10 & 11 & 13 \\
\hline gender $^{b}$ & 0.66 & 0.473 & - & & & & & & & & & & & \\
\hline $\operatorname{age}^{\mathrm{c}}$ & 3.72 & 0.904 & 0.033 & - & & & & & & & & & & \\
\hline position $\mathrm{e}$ & 1.53 & 0.779 & 0.047 & $0.337^{* *}$ & $0.316^{* *}$ & - & & & & & & & & \\
\hline income $^{\mathrm{f}}$ & 2.05 & 0.73 & $0.186^{*}$ & $0.215^{* *}$ & $0.284^{* *}$ & $0.592 * *$ & - & & & & & & & \\
\hline union member $\mathrm{g}$ & 0.68 & 0.468 & 0.044 & 0.004 & -0.066 & 0.05 & 0.075 & - & & & & & & \\
\hline Company size ${ }^{\mathrm{h}}$ & 2.71 & 0.832 & $-0.124^{*}$ & $0.141^{* *}$ & $-0.122 *$ & -0.08 & $-0.264^{* *}$ & -0.004 & - & & & & & \\
\hline company age $^{\mathrm{i}}$ & 2.54 & 0.682 & $-0.125^{*}$ & $0.448^{* *}$ & $-0.111^{*}$ & $0.187^{* *}$ & -0.016 & -0.014 & $0.373^{* *}$ & - & & & & \\
\hline $\begin{array}{c}\text { psychological contract } \\
\text { breach }\end{array}$ & 2.37 & 0.664 & 0.095 & -0.077 & 0.036 & -0.069 & -0.021 & $-0.162^{* *}$ & $-0.117^{*}$ & -0.029 & - & & & \\
\hline union commitment & 2.22 & 0.562 & 0.049 & 0.165 ** & -0.055 & 0.009 & $0.123 *$ & -0.053 & $-0.102 *$ & $0.197 * *$ & $0.219^{* *}$ & - & & \\
\hline organization cynicism & 2.35 & 0.71 & 0.026 & 0.044 & 0.002 & -0.091 & -0.061 & -0.058 & -0.084 & 0.119 * & $0.500 * *$ & $0.228^{* *}$ & - & \\
\hline $\begin{array}{l}\text { perceived union identity } \\
\text { (state-oriented) }\end{array}$ & 3.26 & 0.87 & -0.044 & 0.026 & -0.097 & -0.016 & $-0.270^{* *}$ & -0.037 & $0.257^{* *}$ & $0.143^{* *}$ & $-0.113^{*}$ & $-0.318^{* *}$ & $0.137^{* *}$ & - \\
\hline $\begin{array}{l}\text { perceived union identity } \\
\text { (employee-oriented) }\end{array}$ & 3.74 & 0.634 & 0.004 & $-0.110^{*}$ & 0.096 & 0.028 & -0.082 & 0.066 & 0.1 & -0.06 & $-0.213^{* *}$ & $0.503^{* *}$ & -0.121 * & $0.226^{* *}$ \\
\hline
\end{tabular}

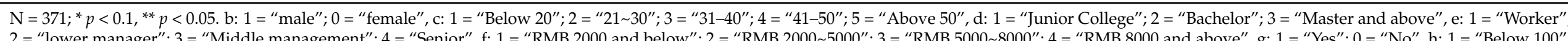

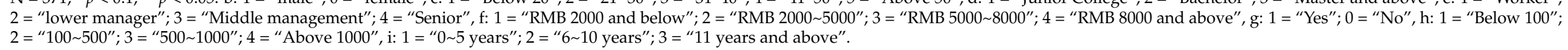


Table 3. Results of a regression analysis of union commitment (mediating model).

\begin{tabular}{|c|c|c|c|c|}
\hline \multirow{2}{*}{ Variables } & \multicolumn{4}{|c|}{ Dependent Variable: Union Commitment } \\
\hline & Model 1 & Model 2 & Model 3 & Model 4 \\
\hline Gender & 0.019 & -0.023 & -0.025 & 0.010 \\
\hline Age & 0.066 & 0.059 & 0.054 & $0.015^{*}$ \\
\hline Education & 0.054 & -0.035 & -0.039 & $-0.03 *$ \\
\hline Position & $-0.109 * *$ & $-0.113^{* *}$ & $-0.104^{* *}$ & $-0.076^{*}$ \\
\hline Income & -0.041 & $0.133^{* * *}$ & $0.137^{* *}$ & 0.114 * \\
\hline Union member & -0.055 & 0.032 & 0.037 & -0.007 \\
\hline Company size & $-0.099 * *$ & $-0.104^{* *}$ & $-0.096^{* *}$ & $-0.064^{* *}$ \\
\hline Company age & $0.171^{* * *}$ & $0.203^{* * *}$ & $0.189 * * *$ & $0.134 *$ \\
\hline Psychological contract breach & & $0.173^{* * *}$ & $0.153^{* *}$ & $0.046^{*}$ \\
\hline Organization cynicism & & & $0.103 *$ & $0.111 *$ \\
\hline Adjust $R^{2}$ & 0.118 & 0.128 & 0.134 & 0.347 \\
\hline $\mathrm{F}$ & $4.542 * * *$ & $7.047^{* * *}$ & $6.703^{* * *}$ & $18.836^{* * *}$ \\
\hline
\end{tabular}

We tested the moderating effect of perceived union identity in the relationship between psychological contract breach and union commitment. Tables 4 and 5 show the results of the regression analyses on union commitment, including a perceived state-oriented union identity and labor-oriented union identity, respectively. The moderated mediation model was tested based on the regression method of Tsui et al. [59]. The mediation effect was confirmed by the Sobel test. The regression coefficient of perceived union identity (state-oriented) is mixed. The regression coefficient of perceived union identity in the mediation model is significantly positive $(\beta=0.241, p<0.01)$. However, such an effect becomes insignificant in a moderated mediation model. Thus, we do not have strong evidence that a state-oriented union identity can increase commitment to union. However, the interaction term of perceived union identity and organization cynicism is significantly negative $(\beta=-0.119, p<0.01)$. It indicates that when combined with organizational cynicism, state-oriented union identity has negative a impact on union commitment. Figure 1 depicts this moderating effect of state-oriented perceived union identity on union commitment. The results support $\mathrm{H} 3$.

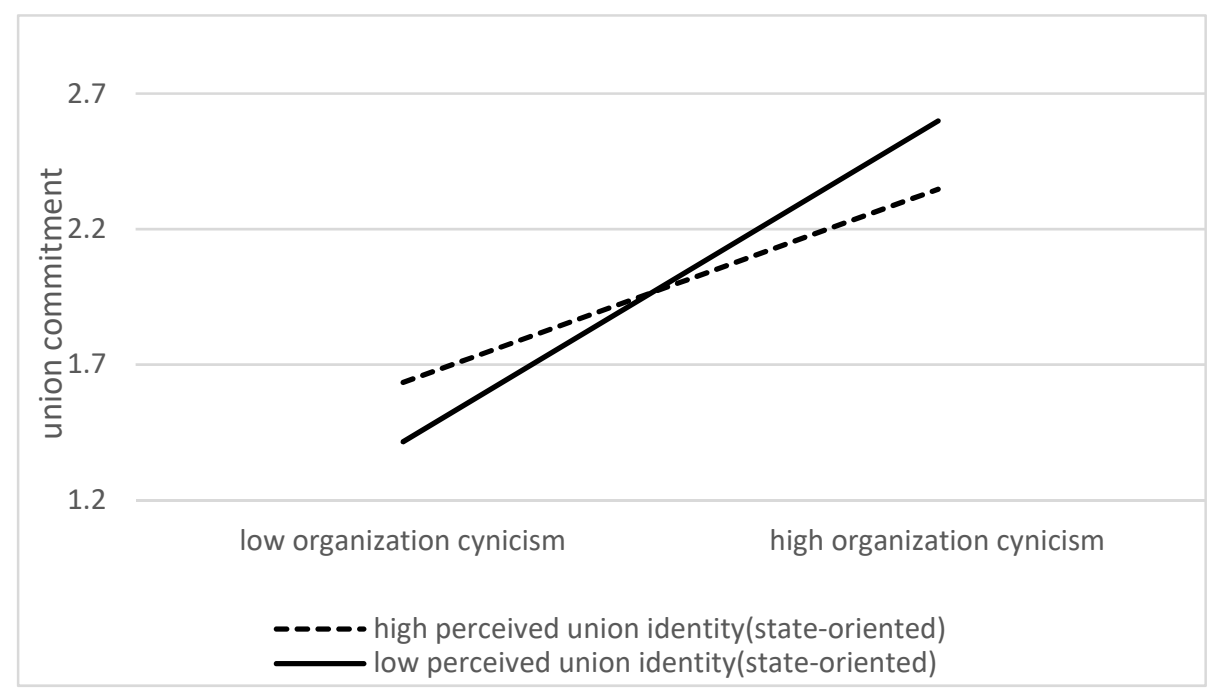

Figure 1. Moderation role of perceived union identity (state-oriented). 
Table 4. Results of a regression analysis of union commitment (moderating effect of perceived state-oriented union identity).

\begin{tabular}{|c|c|c|c|c|}
\hline \multirow{2}{*}{ Variables } & \multicolumn{4}{|c|}{ Dependent Variable: Union Commitment } \\
\hline & Model 1 & Model 2 & Model 3 & Model 4 \\
\hline Gender & -0.023 & -0.025 & -0.026 & -0.025 \\
\hline Age & 0.059 & 0.054 & 0.054 & 0.047 \\
\hline Education & -0.035 & -0.039 & -0.040 & -0.033 \\
\hline Position & $-0.113^{* *}$ & $-0.104^{* *}$ & $-0.102 * *$ & $-0.103^{* *}$ \\
\hline Income & $0.133^{* * *}$ & $0.137^{* *}$ & $0.134^{* *}$ & $0.130 * *$ \\
\hline Union member & 0.032 & 0.037 & 0.038 & 0.030 \\
\hline Company size & $-0.104^{* *}$ & $-0.096^{* *}$ & $-0.095 * *$ & -0.091 \\
\hline Company age & $0.203^{* * *}$ & $0.189^{* * *}$ & $0.189^{* * *}$ & $0.177^{* * *}$ \\
\hline Psychological contract breach & $0.173^{* * *}$ & $0.153^{* *}$ & $0.128^{* *}$ & $0.097 *$ \\
\hline Organization cynicism & & 0.103 * & 0.084 * & $0.473^{* * *}$ \\
\hline $\begin{array}{l}\text { Perceived Union Identity } \\
\text { (state-oriented) }\end{array}$ & & & $0.241 *$ & -0.007 \\
\hline $\begin{array}{l}\text { Organization Cynicism * Perceived } \\
\text { Union Identity (state-oriented) }\end{array}$ & & & & $-0.119^{* *}$ \\
\hline Adjust $\mathrm{R}^{2}$ & 0.128 & 0.134 & 0.131 & 0.147 \\
\hline $\mathrm{F}$ & $7.047^{* * *}$ & $6.703^{* * *}$ & $6.081^{* * *}$ & $6.325^{* * *}$ \\
\hline
\end{tabular}

Table 5. Results of a regression analysis of union commitment (moderating effect of perceived employee-oriented union identity).

\begin{tabular}{|c|c|c|c|c|}
\hline \multirow{2}{*}{ Variables } & \multicolumn{4}{|c|}{ Dependent Variable: Union Commitment } \\
\hline & Model 1 & Model 2 & Model 3 & Model 4 \\
\hline Gender & -0.023 & -0.025 & -0.026 & -0.025 \\
\hline Age & 0.059 & 0.054 & 0.054 & 0.047 \\
\hline Education & -0.035 & -0.039 & -0.040 & -0.033 \\
\hline Position & $-0.113^{* *}$ & $-0.104^{* *}$ & $-0.102 * *$ & $-0.103^{* *}$ \\
\hline Income & $0.133^{* * *}$ & $0.137^{* *}$ & $0.134^{* *}$ & $0.130 * *$ \\
\hline Union member & 0.032 & 0.037 & 0.038 & 0.030 \\
\hline Company size & $-0.104^{* *}$ & $-0.096^{* *}$ & $-0.095 * *$ & -0.091 \\
\hline Company age & $0.203^{* * *}$ & $0.189^{* * *}$ & $0.189 * * *$ & $0.177^{* * *}$ \\
\hline Psychological contract breach & $0.173^{* * *}$ & $0.153^{* *}$ & $0.128 * *$ & $0.097 *$ \\
\hline Organization cynicism & & $0.103 *$ & $0.084 *$ & $0.473^{* * *}$ \\
\hline $\begin{array}{l}\text { Perceived Union Identity } \\
\text { (state-oriented) }\end{array}$ & & & 0.241 * & -0.007 \\
\hline $\begin{array}{l}\text { Organization Cynicism * Perceived } \\
\text { Union Identity (state-oriented) }\end{array}$ & & & & $-0.119^{* *}$ \\
\hline Adjust $\mathrm{R}^{2}$ & 0.128 & 0.134 & 0.131 & 0.147 \\
\hline $\mathrm{F}$ & $7.047^{* * *}$ & $6.703^{* * *}$ & $6.081^{* * *}$ & $6.325^{* * *}$ \\
\hline
\end{tabular}

Lastly, we tested the moderating effect of perceived employee-oriented union identity in the association between psychological contract breach and union commitment. Table 5 
presents the results of the regression analyses on union commitment, including a perceived employee-oriented union identity. The moderated mediation model was also tested and confirmed based on the regression method of Tsui et al. [58]. The effect of perceived union identity (employee-oriented) on union commitment is robust across models and is significantly positive $(\beta=0.086, p<0.01)$, indicating that perceived employee-oriented union identity may increase commitment to union. Moreover, the interaction effect of perceived union identity and organization cynicism is significantly negative $(\beta=-0.119, p<0.01)$, indicating that when combining the two conditions of a high level of organizational cynicism with a high degree of state-oriented union identity, employee commitment to union will be significantly increased.

Figure 2 also illustrates this moderating effect of employee-oriented perceived union identity on union commitment. It shows that when the perceived employee-oriented union identity is higher, the positive relationship between organizational cynicism and union commitment becomes stronger. It implies that the sense of belonging and commitment to union will increase when employees perceive that the union exists as a defender of the employee's interests and when they experience organizational cynicism. Therefore, $\mathrm{H} 4$ is supported.

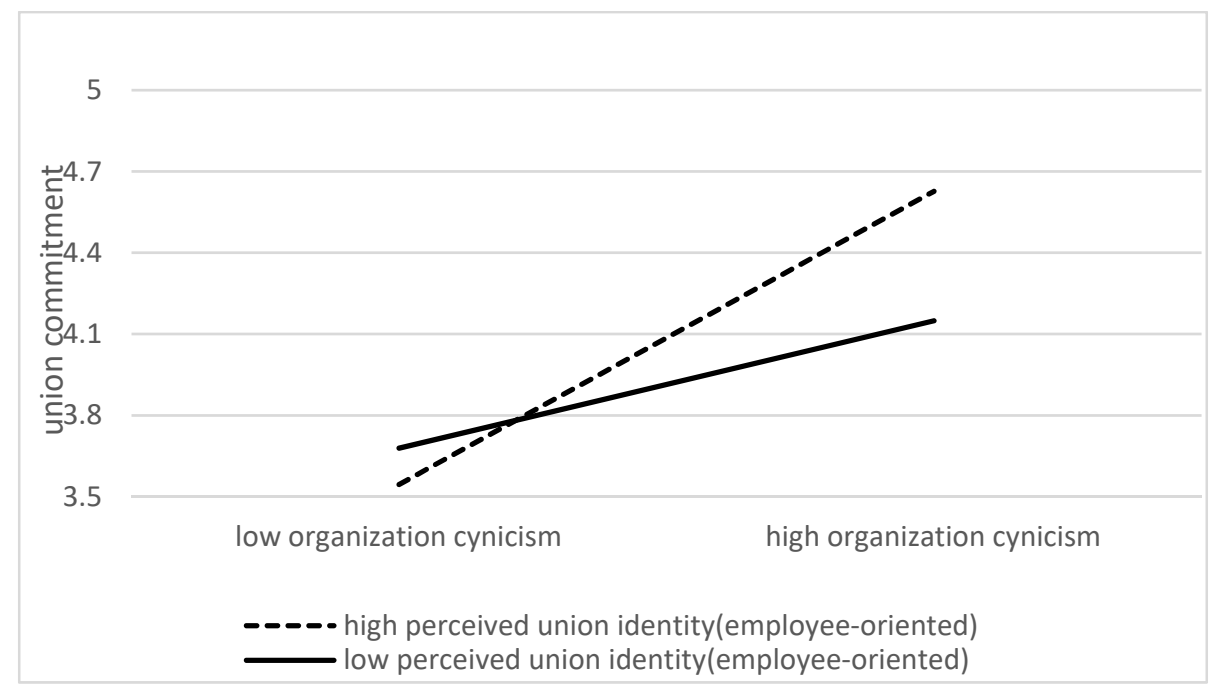

Figure 2. Moderation role of perceived union identity (employee-oriented).

\section{Discussion and Conclusions}

This study examines the relationship between psychological contract breach, organizational cynicism, and union commitment from the social exchange perspective. It is predicted that social exchange involves a series of interactions that generate obligations, and these transactions in the workplace are usually seen as interdependent and contingent on the actions of another [11,12]. Building on the theory, we have determined that these interactions have the potential to generate high-quality relationships, although, as we see, this will occur only under the certain circumstances.

By analyzing the relationship between psychological contract breach and union commitment, the study finds that the former has a positive impact on union commitment; that is, the higher the perception of the breach, the higher the union commitment level. Additionally, the results shows that organizational cynicism plays a partial mediating role in the impact of psychological contract breach on trade union commitment, which indicates that the breach can directly or indirectly affect the latter through organizational cynicism. When employees realize that the psychological contract is broken, they may choose to commit to the union because they have cynicism toward the enterprise $[14,16,59,60]$. They may join a union that can compete with the enterprise to oppose it $[17,61]$. This study examined the moderating effect of perceived union dual identity between organizational cynicism 
and union commitment. The findings indicate that this relationship is weaker when the perceived union identity (state-oriented) is higher; it is stronger when the perceived union identity (labor-oriented) is higher.

Based on the results, this research has the following contributions. Prior research on the psychological contract and union commitment was characterized by mixed results. A few studies call for the need to revisit the effect of psychological contract breach and union commitment $[2,17,18]$. Such empirical inconsistency may imply that organizations vary widely in their capability to manage the negative impact of psychological contract breach. However, few studies have directly examined how such negative effects of psychological contract breach can be attenuated. Thus, we have explored the possibility that employee cynicism plays a mediating role in the process through which psychological contract breach can influence the employee's commitment to union. Moreover, the union identity (labororiented vs. state-oriented) can mitigate the effect of this value-decreasing psychological state. Building on the social exchange perspective, the complexity of the relationship between psychological contract breach and commitment to union is evidenced by the two-way interaction of dual union identity and organizational cynicism.

Moreover, these findings contribute practically to our understanding of union-management relations in China, where limited knowledge exists about union commitment. The findings can help the managers to make strategic decisions, which can reduce feeling of breach of psychological contract, particularly in the Chinese context. Many employees who we interviewed pointed out that false promises by management about career prospects and other benefits ultimately result in breach of psychological contract. Since Chinese unions have played a dual role as an extension of the party and government functions within the enterprise and as a bridge for the communication between the employer and the employee, organizations need to be careful in making promises with the employees. Strong political influence by political parties of the country can lead to a high degree of inequity through favoritism and unjust distribution of organizational rewards. Indeed, many employees tend to show more commitment to unions for protection of their rights. However, this situation can be detrimental to management as presented by Drucker [60] arguing that conflicting interests of management can damage management and unions unless such an environment does not progress where employees are committed to unions without abandoning commitment to organizations. Furthermore, issues such as reciprocal exchange, such as labor-oriented union identity, are important to maintain commitment and trust in the event of psychological contract breach. Therefore, firms should dedicate their efforts to understanding the consequences of implementation of union management strategies.

This study also has limitations, which suggest the need for further study and refinement. First, this research did not have separate response sources for independent and dependent variables, which may have led to the possible common method bias (CMB) problem because the same survey participants presented all relevant information used in the study. We confirmed that CMB is less likely when conducting Harman's one factor model. Second, some possible individual traits that affect the main variables of the study were not included such as personality traits, locus of control (LOC), and some biographical characteristics, such as tenure, skill level, etc. Finally, we did not employee a multilevel analysis to simultaneously examine the relevant firm- and individual-level variables. We believe the individual-level approach as the unit of analysis was proper since we aimed to investigate the relationship between psychological contract breach, employee perception of cynicism and union commitment. However, we believe that multilevel approach may be preferred when investigating organizational cynicism and the impact of individual identity toward union or state and employee commitment to union. Further research calls for a study organizing multilevel study to explore the impact of multilevel firm variables on individual outcomes. 
Author Contributions: J.-Y.A. developed the theoretical approach to psychological contract and the interaction effect of union identity. X.L. conducted the empirical analysis and reviewed the study in the Chinese context. J.H. developed the theoretical approach to organizational cynicism and its mediating effect of psychological contract on union commitment. All authors jointly developed and supported the research model and relationships hypothesized. J.-Y.A. and J.H. contributed to the conclusions, as well as writing, reading and improving the final manuscript. All authors have read and agreed to the published version of the manuscript.

Funding: This research received no external funding.

Data Availability Statement: Publicly available datasets were analyzed in this study.

Conflicts of Interest: The authors declare no conflict of interest.

\section{References}

1. Rousseau, D.M. Psychological Contracts in Organizations; Sage Publications: Thousand Oaks, CA, USA, 1995.

2. Morrison, E.W.; Robinson, S.L. When employees feel betrayed: A model of how psychological contract violation develops. Acad. Manag. Rev. 1997, 22, 226-256. [CrossRef]

3. Coyle-Shapiro, J.; Kessler, I. Exploring Organizationally Directed Citizenship Behaviour: Reciprocity or 'It's my Job'? J. Manag. 2000, 41, 85-106. [CrossRef]

4. Robinson, S.L. Trust and breach of the psychological contract. Adm. Sci. Q. 1996, 41, 574-599. [CrossRef]

5. Robinson, S.L.; Morrison, E.W. Psychological contracts and OCB: The effect of unfulfilled obligations on civic virtue behavior. J. Organ. Behav. 1995, 16, 289-298. [CrossRef]

6. Robinson, S.L.; Rousseau, D.M. Violating the psychological contract: Not the exception but the norm. J. Organ. Behav. 1994, 15, 245-259. [CrossRef]

7. Turnley, W.H.; Feldman, D.C. A discrepancy model of psychological contract violations. Hum. Resour. Manag. Rev. 1999, 9, 367-386. [CrossRef]

8. Haitao, Z.; Hui, C. Research on the relationship between psychological contract violation, organization of cynicism and turnover intention. J. Beijing Labor Soc. Secur. Coll. 2013, 7, 11-14.

9. Sverke, M.; Näswall, K.; Hellgren, J.; Chirumbolo, A.; De Witte, H.; Goslinga, S. European Unions in the Wake of Flexible Production. Available online: http:/ / nile.lub.lu.se/arbarch/saltsa/2002/wlr2002_06 (accessed on 2 January 2020).

10. Peter, A.; Bamberger, P.A.; Kluger, A.N.; Suchard, R. The antecedents and consequences of union commitment: A meta-analysis. Acad. Manag. J. 1999, 42, 304-318.

11. Cook, K.S.; Cheshire, C.; Rice, E.R.W.; Nakagawa, S. Social Exchange Theory. In Handbook of Social Psychology; Handbooks of Sociology and Social Research; DeLamater, J., Ward, A., Eds.; Springer: Dordrecht, The Netherlands, 2013.

12. Kieserling, A. Blau (1964): Exchange and Power in Social Life. In Schlüsselwerke der Netzwerkforschung; Netzwerkforschung; Holzer, B., Stegbauer, C., Eds.; Springer VS: Wiesbaden, Germany, 2019.

13. Conway, N.; Guest, D.; Trenberth, L. Testing the differential effects of changes in psychological contract breach and fulfillment. J. Voc. Behav. 2011, 60, 267-276. [CrossRef]

14. Tekleab, A.G.; Takeuchi, R.; Taylor, M.S. Extending the chain of relationships among organizational justice, social exchange, and employee reactions: The role of contract violations. Acad. Manag. J. 2005, 48, 146-157. [CrossRef]

15. Andersson, L.M. Employee cynicism: An examination using a contract violation framework. Hum. Relat. 1996, 49, 1395-1418. [CrossRef]

16. Johnson, J.L.; O'Leary-Kelly, A.M. The effects of psychological contract breach and organizational cynicism: Not all social exchange violations are created equal. J. Organ. Behav. 2003, 24, 627-647. [CrossRef]

17. Simon, L.D.R.; Hornsey, M.J.; Prashant, B.; Sarah, R.E. Effects of Psychological Contract Breach on Organizational Citizenship Behaviour: Insights from the Group Value Model. J. Occup. Manag. Stud. 2008, 45, 1377-1400.

18. Fiorito, J. Human resource management practices and worker desires for union representation. J. Labor Res. 2001, 22, 335-354. [CrossRef]

19. Blau, P.M. Exchange and Power in Social Life; Wiley: New York, NY, USA, 1964.

20. Cropanzano, R.; Mitchell, M.S. Social exchange theory: An interdisciplinary review. J. Manag. 2005, 31, 874-900. [CrossRef]

21. Turnley, W.H.; Bolino, M.C.; Lester, S.W.; Bloodgood, J.M. The effects of psychological contract breach on union commitment. J. Occup. Organ. Psychol. 2004, 77, 421-428. [CrossRef]

22. Andersson, L.M.; Bateman, T.S. Cynicism in the workplace: Some causes and effects. J. Organ. Behav. 1997, 18, 449-469. [CrossRef]

23. Ferris, G.R.; Arthur, M.M.; Berkson, H.M.; Kaplan, D.M.; Harrell-Cook, G.; Frink, D.D. Toward a social context theory of the human resource management-organization effectiveness relationship. Hum. Resour. Manag. Rev. 1998, 8, 235-264. [CrossRef]

24. Cole, M.S.; Bruch, H.; Vogel, B. Emotion as mediators of the relations between perceived supervisor support and psychological hardiness on employee cynicism. J. Organ. Behav. 2006, 27, 463-484. [CrossRef]

25. Pugh, S.D.; Skarlicki, D.P.; Passell, B.S. After the fall: Layoff victims' trust and cynicism in re-employment. J. Occup. Organ. Psychol. 2003, 76, 201-212. [CrossRef] 
26. Helm, A. Cynics and skeptics: Consumer dispositional trust. Adv. Consum. Res. 2004, 31, 345-351.

27. Kim, T.Y.; Bateman, T.S.; Gilbreath, B.; Andersson, L.M. Top management credibility and employee cynicism: A comprehensive model. Hum. Relat. 2009, 62, 1435-1458. [CrossRef]

28. Davis, W.D.; Gardner, W.L. Perceptions of politics and organizational cynicism: An attributional and leader-member exchange perspective. Leadersh. Q. 2004, 15, 439-465. [CrossRef]

29. Avey, J.B.; Wernsing, T.S.; Luthans, F. Can positive employees help positive organizational change? Impact of psychological capital and emotions on relevant attitudes and behaviors. J. Appl. Behav. Sci. 2008, 44, 48-70. [CrossRef]

30. Clarke, M. Management development: A new role in social change? Manag. Decis. 1999, 37, 767-777. [CrossRef]

31. Thompson, R.C.; Bailey, L.L.; Joseph, K.M.; Worley, J.A.; Williams, C.A. Organizational Change: Effects of Fairness Perceptions on Cynicism; Final Report ADA371588; U.S Department of Transportation: Washington, DC, USA, 1999.

32. Cartwright, S.; Holmes, N. The meaning of work: The challenge of regaining employee engagement and reducing cynicism. Hum. Resour. Manag. Rev. 2006, 16, 199-208. [CrossRef]

33. Simbula, S.; Guglielmi, D. Depersonalization or Cynicism, efficacy or inefficacy: What are the dimensions of teacher burnout? Eur. J. Psychol. Educ. 2010, 25, 301-314. [CrossRef]

34. Naus, F.; van Iterson, A.; Roe, R. Organizational cynicism: Extending the exit, voice, loyalty, and neglect model of employees' responses to adverse conditions in the workplace. Hum. Relat. 2007, 60, 683-718. [CrossRef]

35. Dollard, J.; Doob, L.; Miller, N.; Mowrer, O.; Sears, R. Frustration and Aggression; Yale University Press: New Haven, CT, USA, 1939.

36. Klandermans, B. Psychology and trade union participation: Joining, acting quitting. J. Occup. Psychol. 1986, 59, 189-204. [CrossRef]

37. Kuruvilla, S.; Gallagher, D.G.; Fiorito, J.; Wakabayashi, M. Union participation in Japan: Do Western theories apply? Ind. Labor Relat. Rev. 1990, 43, 374-389. [CrossRef]

38. Monnot, M.J.; Wagner, S.; Beehr, T.A. A contingency model of union commitment and participation: Meta-analysis of the antecedents of militant and nonmilitant activities. J. Organ. Behav. 2010, 32, 1127-1146. [CrossRef]

39. Fleming, P.; Spicer, A. Working at a cynical distance: Implications for power, subjectivity and resistance. Organization 2003, 10, 157-179. [CrossRef]

40. Chang, C.; Sorrentino, C. Research Summaries: Union Membership Statistics in 12 Countries; U.S. Department of Labor: Washington, DC, USA, 1991.

41. Harper, P. The party and the unions in communist China. China Q. 1969, 37, 84-119. [CrossRef]

42. Chen, H.; Chiang, R.H.L.; Storey, V.C. Business intelligence and analytics: From big data to big impact. MIS Q. 2012, 36, 1165-1188. [CrossRef]

43. Zhenglin, Y. On the three great reforms of Chinese trade unions since 1949. Sociol. Stud. 2010, 4, 84-119.

44. Yongli, W.; Yuyu, Z. Analysis of the performance and effect of cross-border functions of trade unions under the dual role positioning. Manag. World 2012, 41, 130-145.

45. Zhao, H.; Wayne, S.J.; Glibkowski, B.C.; Bravo, J. The impact of psychological contract breach on work-related outcomes: A meta-analysis. Pers. Psychol. 2007, 60, 647-680. [CrossRef]

46. Lorenz, E. Neither Friends Nor Strangers: Informal Networks of Subcontracting in French Industry; Gambetta, D., Ed.; Blackwell: New York, NY, USA, 1988.

47. Parkhe, A. Strategic alliance structuring: A game theoretic and transaction cost examination of interfirm cooperation. Acad. Manag. J. 1993, 36, 794-829.

48. Wenxia, Y. Building harmonious labor relations: The path and dimension of trade unions participating in social management innovation. J. China Inst. Labor Relat. 2012, 26, 16-20.

49. Xianguo, Y.; Min, L.; Jun, H. The role of trade unions in labor relations Based on empirical analysis of Zhejiang Province. J. China Inst. Labor Relat. 2009, 23, 31-36.

50. Rousseau, D.M. The individual-organization relationship: The psychological contract. In APA Handbook of Industrial and Organizational Psychology; American Psychological Association: Washington, DC, USA, 2011; Volume 3, pp. $191-220$.

51. Dean, J.W.; Brandes, P.; Dharwadkar, R. Organizational cynicism. Acad. Manag. Rev. 1998, 23, 341-352. [CrossRef]

52. Zhenglin, Y. Three major reforms of Chinese trade unions in the past 60 years. J. Sociol. Stud. 2010, 4, 76-106.

53. Jinglun, Y.; Wenjia, Z. Networking of labor relations and labor solidarity in the age of globalization: Case studies from China's coastal areas. J. Sun Yat-Sen Univ. (Soc. Sci. Ed.) 2010, 50, 161-169.

54. Verma, A.; Kochan, T.A. Unions in the 21st century: Prospects for renewal. In Unions in the 21st Century; Palgrave Macmillan: London, UK, 2004.

55. Loughlin, C.; Barling, J. Young workers' work values, attitudes, and behaviours. J. Occup. Organ. Psychol. 2001, 74, 543-558. [CrossRef]

56. Aiken, L.S.; West, S.G.; Reno, R.R. Multiple Regression: Testing and Interpreting Interactions; Sage Publications: Thousand Oaks, CA, USA, 1991.

57. Baron, R.M.; Kenny, D.A. The moderator-mediator variable distinction in social psychological research: Conceptual, strategic, and statistical considerations. J. Personal. Soc. Psychol. 1986, 51, 1173. [CrossRef]

58. Preacher, K.J.; Hayes, A.F. SPSS and SAS procedures for estimating indirect effects in simple mediation models. Behav. Res. Methods Instrum. Comput. 2004, 36, 717-731. [CrossRef] [PubMed]

59. Tsui, A.S.; Ashford, S.J.; Clair, L.S.; Xin, K.R. Dealing with discrepant expectations: Response strategies and managerial effectiveness. Acad. Manag. J. 1995, 38, 1515-1543. 
60. Drucker, P.F. The New Society: The Anatomy of the Industrial Order; Harper \& Brothers: New York, NY, USA, 1949.

61. Kutaulaa, S.; Gillanib, A.; Budhwar, P.S. An analysis of employment relationships in Asia using psychological contract theory: A review and research agenda. Hum. Resour. Manag. Rev. 2020, 30, 100707. [CrossRef] 